\section{Regards sur l'économie allemande}

Bulletin économique du CIRAC

$110 \mid 2013$

Varia

\title{
Information : les 14-29 ans préfèrent le Web à la TV
}

Isabelle Bourgeois

\section{OpenEdition}

\section{Journals}

Édition électronique

URL : http://journals.openedition.org/rea/4596

DOI : 10.4000/rea.4596

ISSN : 1965-0787

Éditeur

CIRAC

Édition imprimée

Date de publication : 15 octobre 2013

Pagination : 38

ISSN : 1156-8992

\section{Référence électronique}

Isabelle Bourgeois, «Information : les 14-29 ans préfèrent le Web à la TV », Regards sur l'économie allemande [En ligne], 110 | octobre 2013, mis en ligne le 16 octobre 2013, consulté le 15 septembre 2020. URL : http://journals.openedition.org/rea/4596

Ce document a été généré automatiquement le 15 septembre 2020.

(c) CIRAC 


\title{
Information : les 14-29 ans préfèrent le Web à la TV
}

\author{
Isabelle Bourgeois
}

La hiérarchie des sources d'information de tous les Allemands de plus de 14 ans reste certes stable: TV $(60 \%)$, radio $(49,9 \%)$, quotidien $(36,6 \%)$, Internet $(24,7 \%)$, périodiques $(8,4 \%)$. Mais la part de la TV et des quotidiens recule depuis 2009 au profit d'Internet et de la radio. Le changement le plus net s'observe dans la consommation des 14-29 ans; pour eux, Internet vient en tête (49\%), suivi de la TV (26\%) puis des quotidiens $(13,6 \%)$. Et pour se faire une opinion sur le Web, ils préfèrent de loin Facebook (63,8\%), bien avant les portails $(44,6 \%)$ ou les sites des périodiques $(44,8 \%)$. C'est ce qu'il ressort de l'étude 2013 sur la "pertinence des médias pour la formation de l'opinion ", publiée le 06-09 et réalisée en mars par TNS Infratest pour le compte de l'autorité de régulation de l'audiovisuel de Bavière (BLM). (IB)

\section{INDEX}

Mots-clés : information, jeune, groupe social, média, télévision, web, internet, nouvelles technologies, nouveaux média 